Revue Française de Civilisation Britannique

\title{
What Questions Need to Be Asked about the History of the $\mathrm{BBC}$ ?
}

Quelles questions se poser sur l'histoire de la BBC?

\section{John Mullen}

\section{OpenEdition}

\section{Journals}

Electronic version

URL: https://journals.openedition.org/rfcb/7752

DOI: $10.4000 /$ rfcb.7752

ISSN: 2429-4373

\section{Publisher}

CRECIB - Centre de recherche et d'études en civilisation britannique

\section{Electronic reference}

John Mullen, "What Questions Need to Be Asked about the History of the BBC?", Revue Française de Civilisation Britannique [Online], XXVI-1 | 2021, Online since 05 December 2020, connection on 05 January 2022. URL: http://journals.openedition.org/rfcb/7752 ; DOI: https://doi.org/10.4000/rfcb.7752

This text was automatically generated on 5 January 2022.

\section{(9) $\odot \Theta \Theta$}

Revue française de civilisation britannique est mis à disposition selon les termes de la licence Creative Commons Attribution - Pas d'Utilisation Commerciale - Pas de Modification 4.0 International. 


\section{What Questions Need to Be Asked about the History of the $\mathrm{BBC}$ ?}

Quelles questions se poser sur l'histoire de la BBC?

John Mullen

\section{Introduction}

1 The $\mathrm{BBC}$ is one of the oldest and biggest national broadcasters, and its powerful influence has often been written about. Over the decades, it became a symbol of British influence in the world, as well as a much-loved public service, of which many British people are proud. Although the Olympic opening ceremony in 2012 in London, a key opportunity to present the "Best of British" to an audience of hundreds of millions, chose to structure its story of British pride around the Industrial Revolution, the National Health Service and popular music, ${ }^{1}$ the BBC might well have found its way into this canon. The song "I'm So Proud of the BBC" written by comic singer Mitch Benn at a moment the corporation seemed under threat, seemed to many much more than a humorous ditty. ${ }^{2}$ Polls in 2020 show that $62 \%$ of UK citizens have a positive opinion of the $\mathrm{BBC}$, and only $18 \%$ a negative one, even in the highly competitive media landscape of today. ${ }^{3}$

2 Studying the history of the BBC has to be a daunting prospect. Over the 75 years between 1922 and 1995, the classic period of broadcasting, between the foundation of the $\mathrm{BBC}$ and its first productions being made available on the internet, the organization produced over a million hours of programmes. ${ }^{4}$ Producer Huw Weldon liked to say that the $\mathrm{BBC}$ was only the sum of its programmes, ${ }^{5}$ but this immense number makes generalization hazardous, and the examination of some kind of representative sample extremely difficult, even once one has divided the productions into genres of programme. Fortunately, a wide selection of work survives - in particular in television drama, comedy and documentary. Thousands of programmes can be accessed online on YouTube or similar platforms, and the entire scheduled listings of radio and television from the 1920 s on are now available to browse. ${ }^{6}$ 
Given such a huge corpus of programmes, in addition to the stories and archives of the BBC's countless leaders and underlings, it is clear that one cannot simply "let the archive speak" for itself. Which questions are made a priority depends, as always, on the motivations of the historian or other scholar. Our aim here is to present a panorama of questions inspired by different currents of intellectual tradition, in particular varied approaches to historical exploration. Visiting these currents one by one is naturally not intended to suggest that they are lodged in watertight compartments - indeed cross-overs and hybridization of types of history are common and often fruitful.

4 First, general political interrogations. Since the BBC is so universally a symbol of Britishness, and a source of pride for many UK citizens, it is easy to imagine patriotic histories asking "Why did the BBC get it right?" Other political commitments would obviously put forward different interrogations: as early as 1937, the journal The Left Review published a pamphlet entitled "the BBC exposed" which denounced the procapitalist values of the $\mathrm{BBC}$ and insisted that the majority of the Board of Governors should be chosen among representatives of the organized working class. ${ }^{7}$

5 Eighty years later, in 2016, Kate Murphy's Behind the Wireless- A History of Early Women at the $B B C$, asked, inspired by the ideas of feminism, what the true role of women in the 1920s and 1930s was, thus reacting to the dire situation of the existing historiography:

One of the reasons why the image of the $\mathrm{BBC}$ is so masculine is because of the preponderance of memoirs of former employees, all men. It is these accounts, coupled with the masculine-orientated BBC documentation, which form the backbone of most research. ${ }^{8}$

6 General critiques of media power will suggest other explorations. The ideas of Pierre Bourdieu, Stuart Hall or Laura Mulvey on what media do for us or to us will colour our view of everything the $B B C$ produces and its effects. Because, if the leadership of the BBC sets out "to inform, to educate and to entertain", the audience does not meekly sit itself down to be informed, educated or entertained according to the programme notes published in the Radio Times. Uses and gratifications theory demonstrates that consumers have many other things to do with media, and furthermore, we are often entertained by news programmes or educated through fiction or comedy. ${ }^{9}$

7 Pierre Bourdieu's work on television, particularly on television news, emphasized how the spotlight on the spectacular and on the event obscures truths about society. ${ }^{10}$ Everyday suffering in the workplace or in the family tends not to appear on The Nine 0 Clock News in any period, whereas when workers go on strike, this is news. The construction of what news is and is not has an ideological and political effect.

8 Stuart Hall asks, "What is the nature of televisual language?" and "What drives cultural policy makers (given that a neutral "educational" cultural policy is a myth?)" Laura Mulvey explores the question of how women are objectified in film and in narrative television programmes, ${ }^{11}$ and her concept of "the male gaze" is particularly useful when looking at entertainment programmes. The tradition of using women as decorative elements rather than subjects is deeply rooted in our period. A look at the game show The Generation Game ${ }^{12}$ or the music show Top of the Pops ${ }^{13}$ will yield plenty of examples.

9 Meanwhile, Marxist commentators such as John Molyneux, propose questions such as the following, to help understand the place of television in class society: 
Why do TV companies produce The Apprentice ${ }^{14}$ and Dragon's Den ${ }^{15}$ but not How to Be a Trade Union Rep? Why does almost everyone in EastEnders own a small business? Why do all news outlets assume that when stock markets go up, it's good for everyone? And if the media are only "giving people what they want", then why do people want what they want - and is it true that that is all the media are giving them? ${ }^{16}$

\section{Political history} democratic states. Whereas, in the West, it is generally considered inadvisable or even shocking to publish state-controlled newspapers, it is normally thought that public control of some television and radio channels is healthy and necessary. It would be interesting to speculate as to why this is the case. In any case, questions related to political history deserve an important place in our studying. By what mechanisms did governments influence the BBC, given its nominal independence? How successful was this influencing? To what extent can $\mathrm{BBC}$ programmes in times of war or crisis be considered to constitute propaganda? How was the relationship between $\mathrm{BBC}$ and government affected by a change from Conservative to Labour or vice versa? The question of the reasons for the BBC's status as quasi-independent (a status which commentators from other countries can find confusing) is also well worth discussion.

(hernments, Conservative and Labour, have played a central role in the history of the $\mathrm{BBC}$. The corporation was established by government decision under a royal charter, and its monopoly of television until the mid-fifties and of radio until 1973 were political decisions, which were dealt with differently in other democracies. The complete absence of advertising on the BBC was another political choice, and the BBC governors, who, until 2007, appointed the Director-General of the corporation were, in turn, appointed by government. The government could in theory abolish the BBC at any time; yet it could not directly control day to day content. So Prime ministers occasionally consider their interests as poorly served. In 1926, the government was unsure for a moment whether it could trust the BBC to support them appropriately. In the 1980s, Margaret Thatcher was angry at a number of BBC documentaries which were nevertheless screened, and there are other examples of tensions between broadcasting and government. A political history perspective would explore these and also encourage us to ask questions about the effectiveness of different pieces of legislation intended to guide or limit broadcasting. The reputation for independence and fair dealing which the $\mathrm{BBC}$ has often maintained, makes it more effective in defending establishment priorities, and any temptation to tighter governmental control has had to take this into account.

The history of representations will come up more than once in our discussion, and the representations of political actors and debates is one important aspect of this. Since the $\mathrm{BBC}$ has accompanied all the domestic political transformations of the twentieth century (the conflict in Ireland, the rise of Scottish and Welsh nationalism, the rise and crisis of trade unions, the increasing importance of environmental questions, the struggle against sexist or racist oppression, or the victory and then the crisis of multiculturalism, to mention but a few), clearly its relation to these questions is worthy of study, both its presentation of the issues in programmes, fictional and not, and its potential role as encouragement or opposition to change.

Revue Française de Civilisation Britannique, XXVI-1 | 2021 
13 The $\mathrm{BBC}$ is often praised for its impartiality, in the sense that the positions of both major political parties present in parliament find ample airtime for their views, and more radical voices can occasionally be heard. The nature and robustness of such impartiality is an important source of debate and study. It is a complex question. Left and right-wing commentators have often been critical of the $\mathrm{BBC}$ : right-wing commentators because the $\mathrm{BBC}$ has frequently shown itself to be to the left of Conservative governments on "social issues" (homosexuality, education or women's rights, for example), and left-wing commentators because the BBC has generally been to the right of the spectrum on economic issues, consistently presenting strikers, nationalization and labour legislation as a "problem" to be dealt with, and presenting "entrepreneurs", business and the stock market as the engines of a successful nation.

Another question one might ask: does the $\mathrm{BBC}$ merely serve the interests of the Establishment, or is it itself part of it? Governments are sometimes unhappy with the "excessive" impartiality of the BBC. But there have occasionally been signs that BBC management could be more keen to marginalize dissent even than was government. The secret vetting procedures run by MI5 from the 1930s to the 1990s, which the then Director-General lied about in an interview in the Sunday Times in 1968, were not imposed on a reluctant $\mathrm{BBC} .{ }^{17}$ These procedures ensured the $\mathrm{BBC}$ did not employ in positions of influence men and women who were associated with radical left parties such as the Communist Party or the Socialist Workers Party. It is to be noted that when the MI5 proposed relaxing some of these procedures, the leadership of the BBC expressed a desire that they be strictly kept to.

Wider political considerations, as we mentioned above, apply to the general effect of broadcasting on people's view of the world. This question has been at the centre of cultural studies, as it has been developed since its origins in Birmingham University in the UK in the 1960s. One priority of cultural studies is the understanding of how power is exercised through complex cultural practices.

16 It is common to hear ideas about the effect of television on "people in general". Often very simplistic, these are sometimes claims that the mass media make people stupid. Their intellectual heritage can be traced back to Adorno who claimed that the "culture industry" decided what people would like and made them like it, while actually transmitting nothing of cultural value. ${ }^{18}$ These analyses are little followed by researchers today, but have a certain amount of support. Writers like Postman lamented similarly that televisual culture by nature must corrupt culture and information in a way that print culture did not. ${ }^{19}$

17 Although some of these rejections of new media can seem uninteresting in a world where media are omnipresent and are going to remain so, and the criticism may resemble old men's grumpiness about being culturally obsolescent, they do have the advantage of posing wider questions. What does it mean when a TV channel claims to be giving the people what they want? Who decides what people want? What social processes mould our desires for media productions?

\section{Institutional history}

18 An institutional history of the $\mathrm{BBC}$ is indispensable as it allows us to understand the "grammar" of the $\mathrm{BBC}$ and the pressures and room for manoeuvre affecting the 
creative teams who made the programmes. Who were the director-generals, when and by whom were they nominated? What policies did they implement, what services did they establish, what priorities did they push? Asa Briggs's monumental history of UK broadcasting gave much space to this current of historical exploration (although he explored other lines of thought as well).

Between 1927 (when the BBC became a public corporation) and 1995, there were 12 director-generals, all of them men (indeed, to date, there has never been a woman director-general). Each of them might be expected to leave a personal imprint on the role. This was overwhelmingly true of the first - John Reith. When he became directorgeneral there were very few rules and traditions as to how public broadcasting should function, and he was left free rein to do what he felt best. His famously strict Presbyterian religious views had much to do with the principles he put forward, although even he had to react to public and governmental pressure. His personal opinion, whether concerning what kind of programme was appropriate for Sunday broadcasting in what was still a very Christian country, or concerning the importance of recruiting women into significant roles, clearly had considerable weight in those early years. Although later director-generals each had their priorities, it is probably the case that they had less personal power, since the traditions of the job and the increasing number of committees dealing with one or other aspect of the workings of the BBC imposed constraints.

An institutional approach to $\mathrm{BBC}$ history would put considerable emphasis on the dates and functions of various commissions and internal structures. Although the governance of such a corporation can be complex and technical, the wider meaning of some institutional changes can be clearly seen. For example, the establishment in 1926 of the BBC Advisory Committee on Spoken English reflected the worries in educated and influential circles about the "decline" of "proper English". ${ }^{20} \mathrm{John}$ Reith explained:

Happily for us, the officials of our Broadcasting Company have been well chosen, and are all educated and refined men and women, who use cultivated language to which it is a pleasure to listen. Unlike in America, the very tones of our own announcers' voices are an indication of a background of education and culture. ${ }^{21}$

21 The fact that this committee, suspended at the outbreak of the Second World War, was never reactivated after 1945 is highly significant: certain extremes of linguistic and cultural elitism were no longer as acceptable as they previously had been. The democratic spirit of the Welfare State and the rising importance of individual expression in public space may have put paid to the committee's pretentions. Thus, institutional changes are often made under the pressure of social and political change, and in turn transformed the tone of programmes which could be created.

The establishment, in 1936, of the first audience research section in the BBC was, similarly, an institutional change which was a step backward for hard-line Reithianism (Reith had generally considered that the people do not know what is good for them) and it constituted a move towards a far more demand-influenced programming policy. The contours of this influence would trigger heated debates for many decades, indeed up to the present day. A little later, Haley, becoming director-general in the immediate post-war period, had very much a personal input with his concept of the "cultural pyramid", within which radio would try to seduce the masses into cultural elevation, in a more moderate version of Reith's authoritarian broadcasting elitism. ${ }^{22}$ 

take another example of the importance of institutional changes, the transformation of $\mathrm{BBC}$ radio in 1967 (which vastly lifted the profile of popular music on public radio and introduced the DJ style and catchy jingles which had previously been the preserve of non-UK commercial stations) was the result of outside pressure. Audiences wanted the all-day music and chirpiness that the recently banned "pirate" radio stations had provided, while traditional prejudice against popular music which had prevailed inside BBC circles was weakening. In the new set-up, "Radio One" was for all-day pop music, and this institutional change in turn allowed for innovations in broadcasting and in popular music output. Wednesday Play series, which hit the headlines in the 1960 s by broadcasting several radical plays on social issues (such as Up the Junction concerning illegal abortion, or Cathy Come Home concerning homelessness). The memoirs of the producer Tony Garnett show clearly how the structure of the $\mathrm{BBC}$, the very wide leeway allowed to producers, and the clever inventiveness he himself resorted to (for example, deliberately planning key stages in the production process while his superior was on holiday, so as to minimize the chances of censorship), all played a significant part in the broadcasting outcome. ${ }^{23}$ The Wednesday Play episode is often referred to in histories of the $\mathrm{BBC}$, but it is also worth asking "Was it a unique moment never to be repeated?" or even "Did the structures of the BBC subsequently make sure it could never happen again?"

A wider view of the institution's history will place its personnel within wider society. That the BBC has been run by a section of the elite is not a controversial statement. When its first chairman decided to have his portrait painted, he chose to sit for the painting with a sword and white gloves. ${ }^{24}$ In 1936 , when the BBC was looking for a head of their new audience research section, the appointment was made by the elite cooption which was typical at the time. Robert J. E. Silvery was invited to dinner at the London gentleman's club the Garrick club. ${ }^{25}$ The dinner was intended to test his "character" and perhaps find out what kind of a war he had had. The job was not mentioned at all, but offered to him a few days later. ${ }^{26}$

Ten of the twelve director generals who governed the $\mathrm{BBC}$ in our period were privately educated, whereas far less than $10 \%$ of the UK population was. The appropriate questions for the historian to ask here are: by what mechanisms did this elite function? How and why did it become a little less closed as the years went by? And how did its general adhesion to the status quo affect the form and content of programmes?

The strength of the institutional approach to $\mathrm{BBC}$ history is that it allows us to take into account the very specific characteristics of a very unusual organization. Its weakness might be that it could become dry and bureaucratic as an account, like some popular histories of past centuries which vastly over-state the influence of court intrigues on the world. In particular, it cannot explain certain central aspects of broadcasting - the enchantment of everyday life involved, in particular. Briggs notes that early commentators on the arrival of radio often spoke of the "solace" it could bring to the lonely, ill or isolated, either as individuals or as communities - rural life may have been transformed more by radio than urban life was, that window on aspects of the wider world being so much more needed. ${ }^{27}$ The modern reader may have to imagine millions of women at home tasked with housework which was far harsher in those days before most had vacuum cleaners or washing machines, and before detergents had been invented, when supermarkets and ready-made meals were a thing of the future. The

Revue Française de Civilisation Britannique, XXVI-1 | 2021 
radio might well appear then to be something of a miracle companion. In following decades, and particularly with the arrival of the transistor radio, the working days of lorry drivers and taxi drivers, factory workers and cleaners were transformed by this opening onto the world and on their dreams.

\section{Social history}

Social history is one of the great currents which helped pull the discipline out of an excessive concentration on Great Men and Great Events. In Britain, its golden age was during the post-war boom when E. P. Thompson, Eric Hobsbawm, and Christopher Hill were producing their most renowned works. The Collins' dictionary defines social history as "a view of historical events seen in terms of social trends" whereas LexicoOxford speaks of "history with an emphasis on social structures". The history of the BBC has to be linked to social history, because broadcasting is not just something broadcasters do, it is something which is received, used and interpreted by millions of people, alone or in groups, often as families. Over the seventy odd years of our period, these audiences have changed, their lives have changed, and their attitudes have changed, no doubt more quickly than in any previous century. Houses became bigger and families smaller. There was a huge rise in geographical mobility and an intensification of urbanization. We saw more autonomy for young people, the end of single sex education, more ethnic diversity, more possessions (for most of the population), much more education for the masses, less state intervention in people's personal lives and a relative relaxation of strict distinctions between social classes in clothing and in cultural consumption. Life expectancy rose hugely, average working hours per week fell, dangerous physical work became considerably rarer. There was a gradual decline in deference and in religiosity and a gradual rise in the importance of the individual personality and in consumer choice. The productions of the BBC reflect these changes, tell stories about these changes, presenting our lives to ourselves, and express anxiety or satisfaction about change.

One can ask questions about the interaction between changing social structures and broadcasting. One might wonder, for example, about the changes in the conception of a "family programme". A "family programme" on the radio in 1930 is addressed to a larger family in a smaller lodging than a "family programme" on television in the 1980s. In addition, ideas of what might bring consensus in a family have been completely transformed between these two dates - by the 1980s it is expected, for instance, that musical tastes will differ widely between parents and their children, which was far less the case in 1930.

Apart from the effect of broadcasting on socially situated individuals and groups, one can interrogate the changing experience of different social groupings within the production activities of the BBC. The team around David Hendy which is at present putting together the " 100 voices" project on the history of the $\mathrm{BBC}$ has been asking how non-White people working in and with the $\mathrm{BBC}$ analysed their experience, a project not without challenges given the almost complete absence of information on the subject in the written archives of the BBC. Professor Hendy (interviewed in this issue) states his hopes for this adventure, as well as reminding us that all history is, and all historians are, socially situated: 
I hope that we [can] get a more of a 'People's' history of the BBC emerging. Perhaps I'm attracted to this idea anyway, because of my background ... I went to a state school, I don't mix with the Great and Good, I am, in truth suspicious of hierarchies, titles, those who feel they are somehow born to rule.

\section{History of technology}

Political history and social history represent huge swathes of historical scholarship; however, some smaller streams may also provide us with fruitful questions. The history of broadcasting is, for example, closely bound up with the history of technology. The historian will generally look at the development of technology not as a list of improvements to the machines, to be explained by reference to acoustics and electronics, but will be most interested in what new possibilities are thrown up. These often involve people using technology in a manner which its inventors had not necessarily predicted : many of us know the story of how the process of the invention of the internet webcam was helped along by a group of techies who wanted to be able to tell from their desk whether there was coffee left in the coffee jug, without having to go down the corridor to look. ${ }^{28}$

Sometimes, technological changes are decisive. Let us look at just one important moment. In the 1950s, as numbers of television licences grew very rapidly, many in BBC radio were worried that radio was coming to an end, unable to compete with the (relatively) immersive experience of moving pictures on a screen. Two technological inventions helped make sure that this was not the case. The first was that sound quality for listening to music was considerably better on radio than on television. After experiments carried out from 1958, the first regular BBC transmissions using an FM stereo signal began on the BBC's Third Programme network in August 1962. Over the next ten years the technology was improved and stereo became the norm for radio broadcasting.

It was partly as a result of this emerging advantage that $\mathrm{BBC}$ radio programming reoriented itself around music. The major radio relaunch of 1967, in which the Home Service, Light programme and Third Programme were replaced by Radios One to Four, (a numbering system still in place today) involved music at the centre of its priorities: Radio One was to play recent pop and rock, Radio Two popular and variety music in general, while Radio Three would concentrate on classical and opera. 
Japanese-made radio receiver from 1950, before transistors.

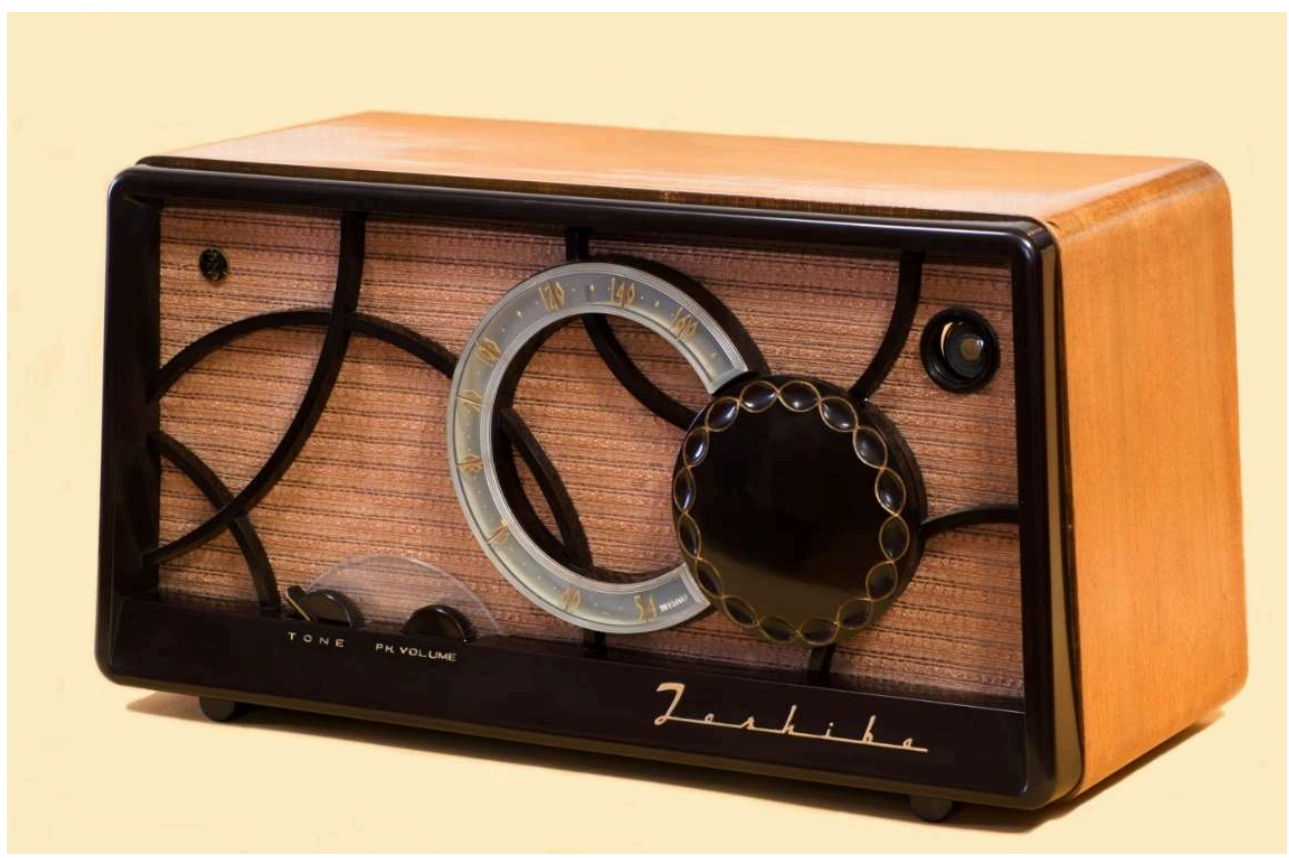

Photo by 池田正樹 - Masaki Ikeda - Own work, Public Domain, https://commons.wikimedia.org/w/ index.php?curid $=6349949$

The second technological change which might be thought of as having saved the radio was the transistor. The radio's two advantages over the television were the fact that it was easy to do something else while listening, and a relative portability, which meant that radios were a common feature of workplaces such as workshops and garages even before transistors. The invention of transistors reduced hugely the weight and size of radios and so the types of workplace or leisure situation in which they could be used. The first transistor radio went on sale in 1954, the cheaper Sony TR 63 was released in 1957. Faced with different audiences, now to be found in their cars, vans, workshops, school playgrounds, in the park or at the seaside, programmes tended to adapt accordingly. How were programmes changed to match the mobile audience? The question is worth asking. 


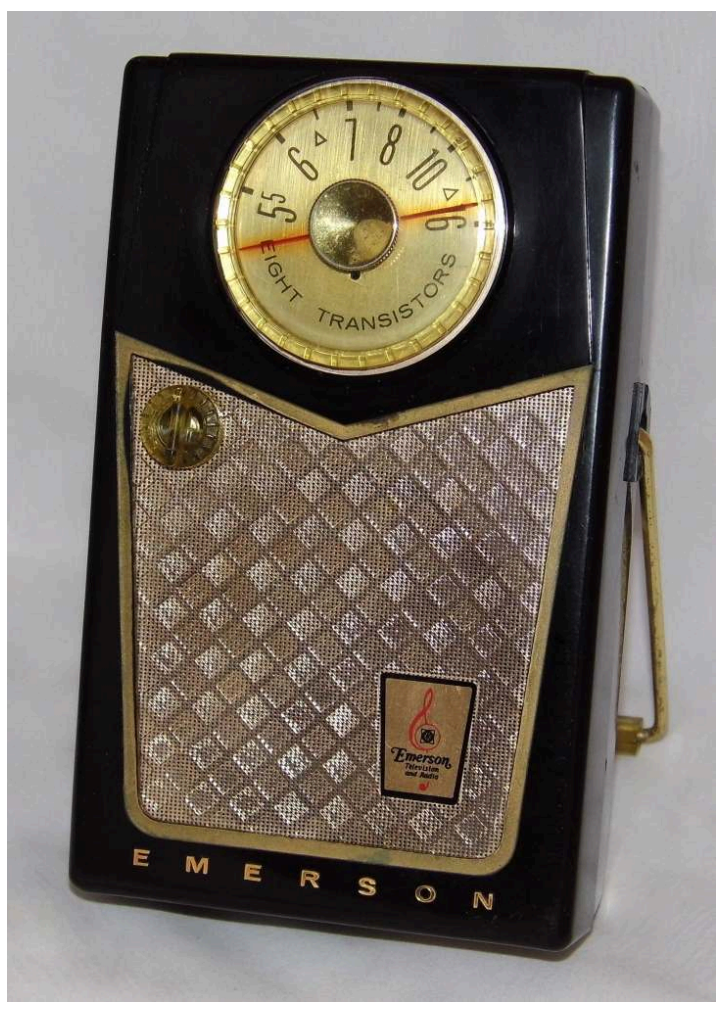

Photo: Joe Haupt from USA - CC BY-SA 2.0, https://commons.wikimedia.org/w/index.php? curid $=45857180$

\section{History of art}

The centre of BBC activity is the creative production of cinematic, musical, dramatic, interactive, informative or playful pieces. Habits of the study of the history of creativity will help us. One important tradition of the history of art is to trace influences between artists, and also to study the development of forms. How did the symphony, the altar triptych, the novel, the cathedral or the sonnet slowly develop as forms of artistic product, when did key changes or innovations come into effect? This tradition can certainly provide ideas for questions to ask of $\mathrm{BBC}$ history. In the first years of radio broadcasting, many forms needed to be invented. Creative directors realized quickly that addressing the microphone as if it were a public meeting was not the best option. The interview, the disc jockey, the quiz show, the radio play or the news bulletin - all these forms needed to be invented. For example, in the early years all interviews were scripted - something we find surprising today when spontaneity of expression is much valued. In the early days radio announcers wore formal dress, and radio plays were played in costume $!^{29}$ During the 1920 s and 1930s, news bulletins moved from being straight read-through texts to including audio inserts from out in the field. The first regular phone-in radio programme did not appear till 1968 (on BBC local radio in Nottingham). Special effects and jingles had to be invented. In later years, one might look at the invention and development of TV soap operas ${ }^{30}$ or sitcoms, documentaries or reality TV shows. ${ }^{31}$ 


\section{Cultural history}

What of "cultural history"? This label is perhaps the most popular among historians these last thirty years, but it is not amenable to a simple definition, since in any case, scholars do not agree on the most useful meaning to attribute to the word "culture". Whereas in everyday life the word is often used solely for artistic endeavours, or only for prestigious artistic activities, academics have looked at it differently. For someone inspired by Marxist ideas, such as Raymond Williams, the culture of a particular period includes all the forms of social organization which are taken for granted in a society the family, the university, the factory, for example, as well as characteristic forms of communication - like broadcasting. ${ }^{32}$ For a cultural anthropologist like Clifford Geertz, culture is most importantly, semiotic. It is made up of "the ensemble of stories we tell ourselves about ourselves" ${ }^{\prime 3}$ It is fair to say that cultural historians can use very wide definitions of culture.

The main strong points of cultural history have been a considerable expansion of what is considered an object of history (giving rise to such sub-genres as "the history of emotions", to give but one example), and a focalization on history from below, that is, on the importance of the lived experience of ordinary people. It has also made a priority of the role of the symbolic in social life: like the anthropologist, cultural historians have chosen to study not merely what people did, but more particularly what it meant to them. As one scholar expressed it: "the common ground of cultural historians might be described as a concern with the symbolic and its interpretation." ${ }^{34}$

Aspects of this approach can help study the history of the BBC. Even if the BBC is the sum of its programmes, watching or listening to a programme does not have the same meaning in different periods. If we imagine a factory canteen or primary school staffroom where people like to discuss the previous day's programmes. These discussions will be very different in 1955 - when only half the staff have a television, and in 1963 - when almost everyone has a television, but only two channels, so one can be sure that everyone knows what was on the previous night, and a popular programme can make a lively subject of debate. In 1993, when half the staff might have cable or satellite TV, or be watching video recorders, the previous night's programmes will have a different cultural meaning again.

An increasingly popular approach to history, linked to cultural history, has been the history of representations, which we have already mentioned. Since radio and television programmes, in particular fictional ones, are about representing our world, our anxieties and our hopes to us (faithfully or not), this aspect of historical enquiry has obvious relevance to the $\mathrm{BBC}$. The transformations and continuities in the representation of, say, working-class people, or of gay men and women supplies a rich field for historical exploration. To take the subject of gay men, who made much progress in fighting discrimination and prejudice from the 1950s onwards, we can see television programmes both reflect and reinforce the prejudices of their time, and can help to transform attitudes. In the period 1955-1975, gays were first generally, then frequently presented as hilarious in themselves. The well-known camp character of $\mathrm{Mr}$ Humphreys in the comedy series Are You Being Served ${ }^{35}$, who was presented as being gay, effeminate and outrageous is a striking example, though almost all fictional productions simply omitted gay people. The show ran for ten series on $\mathrm{BBC} 1$ from 1972-1985, and Mr Humphreys' character was a central part of the programme's 
attraction. The Humphreys persona was harshly criticized by the nascent gay rights movement as locking homosexuality into a very limited stereotype and disallowing any development of a gay character as an ordinary human being.

Avant-garde comedians such as the Monty Python's Flying Circus are rightly remembered for a number of remarkable absurd sketches: several homophobic sketches which they produced have been happily forgotten by the general public.

The counterexample to the comic ridiculing can be found in the extremely popular series EastEnders ${ }^{36}$ which introduced its first gay character in 1985. At this time, gay relationships were not shown on prime-time television. The character, moreover, was presented very much in a positive manner, and his presence was used by the scriptwriters to explore a whole series of questions about homophobia. Colin, the character, kept his sexuality secret when he moved onto the street, and first his friends, then some unsympathetic neighbours, gradually discovered the truth over a period of several months. The audience, too, got to know him before they knew he was gay. Colin was a middle-class man, posher than most on the street, and the arrival of his younger working-class boyfriend allowed the exploration of his character and their relationship. Homophobic prejudice and violence, as well as the legal discrimination at the time (the age of consent was 21 for gay men in the 1980s) became part of the story. Although difficult to measure, the political usefulness of the character in such a popular series may well have been considerably stronger than any number of worthy late-night documentaries on BBC2. Seventeen million people were watching the episode in which "the first gay kiss on prime-time television" was broadcast in November $1987 . .^{37}$

Darrell Newton's important book on the BBC and Black Britons, Paving the Empire Road ${ }^{38}$ is a good example of the kind of questions that a history of representations approach could prioritize:

Historically, what concerns did West Indian organizations express, and what suggestions were made as the $\mathrm{BBC}$ continued to shape programming choices in relation to race and immigration? How did the political climate of the time affect internal decisions made by $\mathrm{BBC}$ management when considering the subject? [...] How could the voices of these new citizens be heard and their desires for social enhancement known? What effect does the absence of these voices have upon a historical study of BBC television?

In the case of Black Britons too, the contradictory role of the BBC is easy to identify. On the one hand, the Corporation could continue showing for many years, despite the protests, such programmes as The Black and White Minstrel Show (1958-1978), ${ }^{39}$ a programme referred to by the mass-circulation Daily Mirror as "the most racist TV show ever". ${ }^{40}$ And the very White nature of almost all British drama in our period is clearly visible. On the other, the treatment of Black characters in soap operas (a TV genre which is very much about inclusion, about talking about "our folk") pushed in the other direction, and documentary series such as Panorama would very occasionally produce sympathetic pieces about immigrant groups, as they did in December 1974, looking at "A report on the plight of Pakistanis facing a four-year wait to join relatives living in Britain ", or in 1984, looking at schooling difficulties for Asian children in Bradford. The production of programmes for immigrants such as Make Yourself at Home (Apna Hi Ghar Samajhiye), which, with various name changes ran from 1965-1987, or of the 1978-79 soap opera, Empire Road, set in a street of mostly non-white residents also 
tended towards a recognition of Britain as a place which did not have to be wholly White.

\section{Global history}

In recent years, global history has become more influential in universities across the world, in reaction both to the fact that historians in each country have massively concentrated on just their country, and to the fact that history has often been Eurocentric. One of the field's priorities is the study of a past "understood primarily as the history of entanglements", relying on "the general insight that no society, nation or civilization exists in isolation." ${ }^{41}$

Since BBC productions have been consumed around the world, and have been instrumental in constructing an image of Britain useful to British power, soft or otherwise, some of the perspectives of global history are clearly relevant. Concerning British colonialism, there are (at least) two sides to such explorations. Firstly, how did the activities of the BBC abroad help colonialist and imperial projects? The naming of the BBC Empire Service, when it was founded in 1932, was of course no accident, even though it was renamed the overseas service only six years later. Though foreign language programming was important, the focus of the world service for decades was on White British people living in the colonies. Its foreign language programmes meanwhile no doubt counted as soft power, ${ }^{42}$ and supporting colonialism, while it lasted, was generally a foregone conclusion for BBC executives. Secondly, how were the colonies and their peoples presented to a domestic British audience? How was decolonization and its results explained and represented? ${ }^{43}$

Other aspects of "entangled history" also have their importance: how did the BBC influence broadcasting organization and policies abroad, in the United States or in the former colonies? From Reith's almost missionary visits to South Africa and Australia in the 1920 s to the many projects of international cooperation in the 1970s and 1980s, international thinking and activity has loomed large

\section{Conclusion}

The aim of this contribution has been to explore a large number of questions that can be asked about the history of the $\mathrm{BBC}$, by visiting different currents of historical interpretation and suggesting questions which each approach might prioritize. The presentation has been far from exhaustive, but has served to underline the main danger in this or any other historical exploration - that of keeping the questions excessively narrow. Of course, the answer to the question in the title - what questions need to be asked - must necessarily depend on the priorities of each observer. It is clear that the student of the BBC and its history should not be short of questions to ask, and should always be keen to find new ones. 


\section{BIBLIOGRAPHY}

Adorno, Theodor, The Culture Industry: Selected Essays in Mass Culture (London, Routledge, 2001).

Alvarado, Manuel, Buonanno, Milly et al, The SAGE Handbook of Television Studies (New York, Sage, 2014).

Audit, George, The BBC Exposed (London, Left Review, 1937).

Bourdieu, Pierre, Sur la télévision (Paris, Raisons d'agir, 1996).

Briggs, Asa, “The Culture of the BBC: A Personal Appreciation”, Revue LISA/LISA e-journal, vol 2, janvier 2004.

Briggs, Asa, The History of Broadcasting in the United Kingdom, Volume 1: Birth of Broadcasting, (Oxford, Oxford University Press, 1995) [First edition 1961].

Briggs, Asa, The History of Broadcasting in the United Kingdom, Volume 2: The Golden Age of Wireless, (Oxford, Oxford University Press, 1995) [First edition 1965].

Burke, Peter, What is Cultural History? (London, Polity, 2013).

Conrad, Sebastian, What is Global History? (Princeton, Princeton University press, 2016).

Franks, Suzanne, "BBC Reporting in India in the 1970s and 1980s: Globally Connected Media

Ahead of Its Time", Historical Journal of Film, Radio and Television, 32:2, 2012

Geertz, Clifford, The Interpretation of Culture (London, Hutchinson, 1975).

Healey, Murray, "Were we being served? Homosexual representation in popular British comedy", Screen, Volume 36, Issue 3, Summer 1995.

Molyneux, John, Will the Revolution be Televised? A Marxist Analysis of the Media (London, Bookmarks, 2011).

Mullen, John, "La BBC et la musique populaire 1922-1995" in Georges Fournier et al, La BBC et le service public de l'audiovisuel, 1922- 1995 (Paris, Ellipses, 2020).

Mulvey, Laura, Afterimages: On Cinema, Women and Changing Times (London, Reaktion, 2019).

Murphy, Kate, Behind the Wireless, A History of Early Women at the BBC (London, Palgrave Macmillan, 2016).

Newton, Darrell, Paving the Empire Road - BBC Television and Black Britons (Manchester, Manchester University press, 2011).

Postman, Neil, Amusing Ourselves to Death (London, Methuen, 1987).

Schwyter, Jürg, Dictating to the Mob, the History of the BBC Advisory Committee on Spoken English (Oxford, Oxford University Press, 2016).

Silvery, Robert J. E., Who's Listening?: The Story of BBC Audience Research (London, Routledge, 2018).

Williams, Raymond, The Long Revolution (Cardigan, Parthian, 2011). [First edition 1961].

\section{NOTES}

1. Can be viewed online here https://www.youtube.com/watch?v=4As0e4de-rI 
2. This piece can be heard online here https://www.youtube.com/watch?v=YzqfYV-6olc

3. See https://yougov.co.uk/topics/consumer/explore/brand/BBC

4. The $B B C$ reckons there were three million programmes broadcast in the period 1922-2002 https://www.bbc.co.uk/blogs/aboutthebbc/entries/0b693e85-0d09-3a26-b0f5-512bf2a74413

5. Quoted in Asa Briggs, "The Culture of the BBC: A Personal Appreciation ", Revue LISA/LISA ejournal, Média, culture, histoire, Images et média, vol 2, janvier 2004.

6. In a developing, interactive archive, here : https://genome.ch.bbc.co.uk/

7. George Audit, The BBC Exposed (London, Left Review, 1937).

8. Kate Murphy, Behind the Wireless, A History of Early Women at the BBC (London, Palgrave Macmillan, 2016).

9. Manuel Alvarado, Milly Buonanno et al, The SAGE Handbook of Television Studies (New York, Sage, 2014), ch 7.

10. Pierre Bourdieu, Sur la télévision (Paris, Raisons d'agir, 1996).

11. Laura Mulvey, Afterimages: On Cinema, Women and Changing Times (London, Reaktion, 2019).

12. Episode available online here https://www.youtube.com/watch?v=fhtc4NH4s_A\&

13. John Mullen, « La BBC et la musique populaire 1922-1995 » in Georges Fournier et al, La BBC et le service public de l'audiovisuel, 1922- 1995 (Paris, Ellipses, 2020).

14. A very popular reality TV series produced in the USA from 2004, and in its British version from 2006, testing how good people are at being corporate businessmen in a tough market.

15. A reality TV series originating in Japan $\mathrm{n}$ 2001, with its British version first broadcast in 2005. Small business men and women must pitch their ideas to venture capitalists in the hope of persuading them to invest.

16. John Molyneux, Will the Revolution be Televised? A Marxist Analysis of the Media (London, Bookmarks, 2011), p.126.

17. "The vetting files: How the BBC kept out 'subversives' ", BBC News, 21 April 2018, https:// www.bbc.com/news/stories-43754737

18. Theodor Adorno, The Culture Industry: Selected Essays in Mass Culture (London, Routledge, 2001, reprints of his work between the 1930s and the 1960s).

19. Neil Postman, Amusing Ourselves to Death, (London, Methuen, 1987).

20. The history of this committee is told in Jürg Schwyter, Dictating to the Mob, the History of the BBC Advisory Committee on Spoken English (Oxford, Oxford University Press, 2016). The title of the book emphasizes the social dynamics involved in the committee's work.

21. Op. Cit., p20.

22. Renée Dickason, La BBC dans le paysage audiovisuel britannique (Paris, Belin, 2020), p.67.

23. See the article in this issue.

24. Asa Briggs, The History of Broadcasting in the United Kingdom, Volume 1: Birth of Broadcasting (Oxford, Oxford University Press, 1995) (1961), p.136.

25. Even in 2020, this club does not admit women as members.

26. Robert J. E. Silvery, Who's Listening?: The Story of BBC Audience Research (London, Routledge, 2018), p.13.

27. Asa Briggs The History of Broadcasting in the United Kingdom, Volume 2, The Golden Age of Wireless, (Oxford, Oxford University Press, 1965), p.12, p.237.

28. https://www.bbc.com/news/technology-20439301

29. Some aspects of this are explained in parts of this documentary « The History of Pop Radio, part one ", available online here : https://www.youtube.com/watch?v=n8T9Z6bmetg\&

30. The soap opera, despite its humorous name, introduced new rules to a dramatic presentation - there was no end to the story where everything got tidily wrapped up, there was no single hero or narrative centre. 
31. Although reality TV rose into prominence in the 1990s, there were many precursors, including BBC shows such as The Big Time (1976-80) see a video about this programme here: https://www.youtube.com/watch?v=xXMB3hNeSIU\&

32. Raymond Williams, The Long Revolution, (Cardigan, Parthian, 2011), chapter 2 [First edition 1961].

33. Clifford Geertz, The Interpretation of Culture, (London, Hutchinson, 1975), p448, p452.

34. Peter Burke, What is Cultural History (London, Polity, 2008).

35. Murray Healey, «Were we being served? Homosexual representation in popular British comedy ", Screen, Volume 36, Issue 3, Summer 1995.

36. Broadcast continuously by the BBC two or three times a week since 1985, EastEnders presents the life of people living in an ordinary street in London.

37. The actor who played Colin recalls the story in a short interview available here: https:// www.youtube.com/watch?v=qy0zBk3qtgM

38. Darrell Newton, Paving the Empire Road - BBC Television and Black Britons (Manchester, Manchester University Press, 2011). See review in this issue.

39. A very short 21st century report on this programme https://www.youtube.com/watch? v=b4tGthUWW_s.

40. Daily Mirror 23 July 2013 https://www.mirror.co.uk/tv/tv-news/black-white-minstrel-showmost-2077085

41. Sebastian Conrad, What is Global History? (Princeton, Princeton University press, 2016), p.9.

42. See article in this issue.

43. Suzanne Franks "BBC Reporting in India in the 1970s and 1980s: Globally Connected Media Ahead of Its Time", Historical Journal of Film, Radio and Television, 32:2, 2012.

\section{ABSTRACTS}

The BBC produced, between 1922 and 1995, over a million hours of programmes. In the face of such a massive corpus, strategies for understanding and recounting BBC history are necessarily challenging, and there is a real danger of being satisfied with a simplified, institutional, top-down approach. This contribution takes us on a tour of different currents of historical and cultural research to suggest some particularly fruitful questions about the history of the $\mathrm{BBC}$, among the huge panorama of possible interrogations.

Entre 1922 et 1995, la BBC a produit plus d'un million d'heures d'émissions. Du fait de ce corpus, l'écriture de son histoire constitue une véritable gageure, et il existe un danger que nous nous satisfassions d'une histoire simplifiée, purement institutionnelle. Cette contribution va chercher, chez les acteurs de divers courants historiographiques, quelques-unes des questions fructueuses parmi le nombre immense d'interrogations possibles.

\section{INDEX}

Keywords: $\mathrm{BBC}$, media studies, propaganda, enchantment, historiography

Mots-clés: $\mathrm{BBC}$, études des médias, propagande, enchantement, historiographie 


\section{AUTHOR}

\section{JOHN MULLEN}

Université de Rouen, Equipe ERIAC

John Mullen is Professor of British Studies at the University of Rouen. He has published widely on the history of British popular music, as well as on questions of historiography. He wrote The Show Must Go On-Popular Song in Britain during the First World War (Routledge 2015) and edited Popular Song in the First World War, an International Perspective (Routledge 2018). 